\title{
Okul Öncesi Dönem Çocuklarının Çoklu Zekâ Alanları ile Çevreye Karşı Tutumlarının İncelenmesi ${ }^{1}$
}

\author{
Hilal GENÇ² ve Emel ARSLAN ${ }^{3}$
}

$\ddot{\mathrm{O} z}$

Bu çalş̧mada, okul öncesi dönem çocuklarının çoklu zekâ alanları ile çevreye karşı tutumlarının incelenmesi amaçlanmıştır. Ayrıca çocukların çevreye karşı tutumlarının cinsiyet ve okul öncesi eğitimi alma ve almama değişkenlerine göre farklılaşıp farklılaşmadığı incelenmiştir. Araştırma genel tarama modelinde yürütülmüştür. Araştırmanın örneklemi basit tesadüfí örnekleme yöntemiyle seçilen Konya ilinin Meram ilçesinde yaşayan 452 çocuktan oluşmaktadır. Araştırmada veri toplama aracı olarak; "Kişisel Bilgi Formu", Teele (1997) tarafindan geliştirilen Özdemir (2006) ve Öztürk (2012) tarafından Türkçeye uyarlaması yapılan TIMI Teele Çoklu Zekâ Envanteri ve Evans ve diğerleri (2007) tarafindan geliştirilen Cevher-Kalburan (2009) tarafindan Türkçeye uyarlaması yapılan Çocuklar için Çevre Tutum Ölçeği kullanılmıştır. Verilerin analizinde, betimsel istatistikler, t-testi, iki faktörlü ANOVA, korelasyon ve regresyon analizi kullanılmıştır. Araştırmadan elde edilen bulgulara göre, okul öncesi dönemdeki çocukların sosyal zekâ alanları ile çevresel tutum puanları arasında anlamlı bir ilişki bulunmuştur. Çocukların cinsiyetlerine göre çevresel tutum puanları arasında anlamlı bir farklılık olmadığı tespit edilmiştir.

Anahtar Kelimeler: Çoklu Zekâ Kuramı, Çevresel Tutum, Okul Öncesi Eğitim

\section{Investigating Pre-School Children's Attitudes towards Environment through Multiple} Intelligences

\begin{abstract}
The research aimed at studying the relationship of pre-school children towards environments environment through multiple intelligences areas. In addition, we investigated whether the attitudes of children towards the environment differed according to two variables: gender and whether children received pre-school education or not. The general survey method was used in this research. 452 children living in the Meram district of Konya Province were selected using a simple random sampling method. The data collection tools were Personal Information Form, TIMI (Teele Inventory for Multiple Intelligences) which was created by Teele (1997) and adapted into Turkish by Özdemir (2006) and Öztürk (2012) and Children's Environmental Attitude Scale which was created by Evans others (2007) and adapted into Turkish by Cevher-Kalburan (2009) were used as data collection tools. Descriptive statistics, correlation, t-test, regression, two-factor ANOVA were used for data analysis. According to results of the study, there was a statistically positive relationship between children's interpersonal intelligences and environmental attitudes. No significant difference was found in the attitudes of the children towards environment in terms of gender variable.
\end{abstract}

Key Words: Multiple Intelligences Theory, Environmental Attitude, Pre-School Education

\section{Atıf İçin / Please Cite As:}

Genç, H. ve Arslan, E. (2020). Okul öncesi dönem çocuklarının çoklu zekâ alanları ile çevreye karşı tutumlarının incelenmesi. Manas Sosyal Araştırmalar Dergisi, 9(2), 719-730.

Geliş Tarihi / Received Date: 12.06.2019

Kabul Tarihi / Accepted Date: 25.07.2019

\footnotetext{
${ }^{1}$ Prof. Dr. Emel Arslan’ın danışmanlığında yürütülmüş olan bu çalısma, Arş. Gör. Hilal Genç’in “Okul öncesi dönem çocuklarının çoklu zekâ alanları ile çevreye karșı tutumlarının incelenmesi" (2015) bașlıklı yüksek lisans tezinden türetilmiștir. Bu çalıșma, 26-27 Temmuz 2017 tarihlerinde Barcelona/İspanya'da düzenlenen“20th International Conference on Teaching, Education \& Learning (ICTEL)" adlı kongrede sözlü bildiri olarak sunulmuştur.

2 Arş. Gör. - Kırşehir Ahi Evran Üniversitesi Eğitim Fakültesi, hilal.genc40@gmail.com ORCID: 0000-0002-3030-2080

3 Prof. Dr. - Necmettin Erbakan Üniversitesi Ahmet Keleşoğlu Eğitim Fakültesi, emelarslan@erbakan.edu.tr ORCID: 0000-0002-1294-0855
} 


\section{Giriş}

Çevre problemleri çözülmesi gereken toplumsal problemlerin başında yer almaktadır. Kirlilik, küresel iklim değişikliği ve dünyanın doğal kaynaklarının tükenmesi gibi çevresel problemler bireyleri, toplulukları ve canlıları tehdit etmektedir (Bruni, Chance ve Schultz, 2012, s. 1). İnsanların ve diğer canlıların daha sağlıklı, temiz ve güvenilir bir dünyada yaşamlarını sürdürmeleri için çevre konuları hakkında bilinçli ve çevresel sorunlara duyarlı bireyler yetiştirmek zorunlu hale gelmiştir (Mert, 2006, s. 66; Şahin, Cerrah, Saka ve Şahin, 2004, s. 114; Özdemir, 2007, s. 25).

Çevresel tutum bireyin çevreye ilişkin konulara, çevreyi kullanmaya ve korumaya yönelik duygu, inanış ve davranışlarıdır (Bogner ve Wiseman, 2006, s. 247-254; Schultz, Shriver, Tabanico ve Khazian, 2004, s. 31). Bireyin çevresel tutumu ve çevreye yönelik değerleri çevre eğitimi ile geliştirilebilir (Lieflander ve Bogner, 2016, s. 612). Çevre eğitimi ile bireyin çevresel sorunları tanımlaması, sorunların çözümü için gerekli becerileri öğrenmesi ve çevresel sorunlarla başa çıkma için aktif katılımının sağlanması amaçlanmaktadır (UNESCO/UNEP, 1977, s. 144). Ayrıca çevre eğitimi, bireyin yaşam dünyası hakkında tutum geliştirmesine, değerlerini keşfetmesine, doğal kaynakların kullanımı ve çevresel konularda bilgi edinmesine yardım eder (Monroe, Andrews ve Biedenweg, 2007, s. 206). Dolayısıyla çevre eğitiminin bilişsel ve duyuşsal alanda amaçları bulunmaktadır (Tanrıverdi, 2012, s. 30-36).

Çevre eğitimi yaşamın ilk yllarından itibaren örgün ve yaygın eğitimde önemli bir yere sahiptir. Bu nedenle çevre eğitimi sadece sınılı bir zaman diliminde uygulanan bir öğretim programı ile kısıtlanmamalıdır. Okul öncesi dönemden başlayarak, eğitim ortamlarında verilecek çevre eğitimi ile çocuklarda çevreye duyarlı davranış ve tutumların yerleşmesi, doğaya karşı empati becerisinin gelişmesi ve sevginin oluşması mümkün olmaktadır (Andrejewski, 2011, s. 150; Erten, 2004, s. 3-4; Kesicioğlu, 2008, s. 67-71; Özdemir, 2007, s. 38).

Çocukların dünyası genişledikçe, yaşadıkları gezegeni daha çok merak edip ilgilenirler. Bu nedenle çevre eğitimiyle ilgili uygulamalar yapılırken küçük çocukların ilgi ve merak duygularından hareket edilmelidir (Buhan, 2006, s. 37). Ayrıca çocukların gelişim özelliklerinin de dikkate alınması gerekmektedir (Haktanır, 2007, s. 19). Tuğrul ve Duran'a (2003, s. 233) göre; çocukların öğrenme ihtiyaçlarının karşılanması için gelişim alanları desteklenmelidir. Çocuklar aynı öğrenme ortamından farklı şekillerde etkilenirler. Öğrenme öğretme sürecinin etkililiği çocukların bireysel öğrenme biçimlerinde, ilgi ve gereksinimlerine yönelik firsatlar sunularak arttırlabilir. Bu nedenle çocuklara çeşitli deneyim imkânları sunularak zenginleştirilmiş ortamlarda öğrenmeleri sağlanmalıdır.

Çoklu Zekâ Kuramı'na göre hazırlanan eğitim ortamları, çocuklara kendi öğrenme biçimlerine uygun gelişimsel bir firsat sunabilir. Gardner, "Zihnin Çerçeveleri”" adlı eserinde bir insanın; Sözel-Dil, Mantıksal-Matematiksel, Görsel-Uzamsal, Bedensel-Kinestetik, Müzikal-Ritmik, Sosyal ve İçsel Zekâ olmak üzere yedi zekâ alanından oluşan yeteneklere sahip olduğunu vurgulamaktadır. Gardner, bir problemi çözme ya da farklı bir yoldan bir ürün ortaya koyma yeteneklerini zekâ olarak adlandırmaktadır (2011, s. 63-74). Gardner Çoklu Zekâ Kuramı'nı ileri sürdüğü ilk yıllarda, zekâ alanlarının yediden daha fazla sayıda olabileceğini ifade etmiştir ve daha sonraki yıllarda doğa zekâsını da sekizinci zekâ alanı olarak belirlemiştir (Saban, 2010, s. 8-20; Demirel, Başbay ve Erdem, 2006, s. 13-16; Fleetham, 2006, s. 18-19). Dokuzuncu zekânın varoluşla ilgili olabileceğini düşünen Gardner bu zekâ alanına "Varoluş Zekâsı" adını vermektedir. Ancak çalışmaların nasıl sonuçlanacağı belli değildir. Çünkü Gardner'ın henüz varoluşsal zekâ ile ilgili yeterli kanıtı bulunmamaktadır (Demirel vd., 2006, s. 15; Fleetham, 2014, s. 10).

Çoklu zekâ kuramı ile çocukların zekâ alanlarının tespit edilerek ilgi ve yetenekleri doğrultusunda eğitim programları uygulanabilir ve eğitim programlarında bütün zekâ alanlarına eşit düzeyde önem vererek farklı zekâ alanlarındaki gelişimleri desteklenebilir (Saban, 2010, s. 2). Bireyin problem çözme, düşünme ve akıl yürütme yeteneği olarak adlandırılan zekânın tutum ve davranışları üzerinde önemli etkisi vardır (Kahyaoğlu, 2013, s.163). İlgili literatür incelendiğinde, okul öncesi dönemde çevre tutumunu, farkındalığını ve bilincini inceleyen çok sayıda çalışmaya rastlanmaktadır (Çabuk, 2001, s. 9-10; KahrimanÖztürk, 2010, s. 6; Kesicioğlu, 2008, s. 3; Miller, 2007, s. 49-66; Tanrıverdi, 2012, s. 8). Çevre tutumunun ve çoklu zekâ alanları ile ilişkisini inceleyen sınırlı sayıda çalışmaya rastlanılmıştır. Ancak bu çalışmalar okul öncesi dönem çocuklarını kapsamayıp diğer öğretim kademeleirini kapsamaktadır (Arslanyolu, 2010, s. 2; Baş, 2010, s. 59-60; Kahyaoğlu, 2013, s. 163). Dolayısıyla okul öncesi dönemde çocukların çevreye karş1 tutumlarının sahip oldukları farklı zekâ alanlarına göre incelenmesi ile elde edilen sonuçlar, çevre eğitimi etkinlikleri bağlamında çocukların ilgi ve yetenek farklılıklarını ortaya çıkarması ve eğitim programları hazırlanırken bireysel farklılıkların göz önünde bulundurulması açısından önemlidir. Bu nedenle bu 
çalışmada, okul öncesi dönem çocuklarının çoklu zekâ alanları ile çevreye karşı tutumlarının incelenmesi amaçlanmaktadır. Bu doğrultuda aşağıda belirtilen sorulara cevap aranmıştır:

1. Okul öncesi dönem çocuklarının çevreye karşı tutum puan ortalamaları cinsiyete göre anlamlı bir farklilik göstermekte midir?

2. Okul öncesi dönem çocuklarının çevreye karşı tutum puan ortalamaları daha önceki yıllarda okul öncesi eğitimi alma veya almama durumlarına (devam etmekte oldukları anasınıfı veya bağımsız anaokulundan önceki anaokulu deneyimleri) göre anlamlı bir farkll1ık göstermekte midir?

3. Okul öncesi dönem çocuklarının çoklu zekâ kuramındaki zekâ alan puanları ile çevreye karşı tutum puanları arasında ilişki var mıdır?

4. Okul öncesi dönem çocuklarının zekâ alanları, çevresel tutumlarını anlamlı bir şekilde yordamakta midir?

5. Okul öncesi dönem çocuklarının çevreye karşı tutum puan ortalaması okul öncesi eğitimi alıp almama durumları ve çoklu zekâ alanlarının puan ortalamalarına göre anlamlı düzeyde farklılaşmakta mıdır?

\section{Yöntem}

$\mathrm{Bu}$ araştırmada, nicel araştırma modellerinden genel tarama modeli kullanılmıştır. Genel tarama modeli, çok sayıda eleman içeren bir evren hakkında genel bir yargı elde etmek için, evrenin tamamı veya evrenden alınan örneklem ile yapılan tarama çalışmalarıdır (Karasar, 2014, s. 79). Bu model çerçevesinde okul öncesi dönem çocuklarının çoklu zekâ alanları ile çevreye karşı tutumları incelenmiştir.

\section{Evren - Örneklem}

Araştırma evrenini, 2014-2015 eğitim-öğretim yllında Konya ilinin Meram ilçesinde Milli Eğitim Bakanlığına bağlı ilkokullardaki anasınıflarına ve bağımsız anaokullarına devam eden altı yaş grubundaki çocuklar oluşturmaktadır. Araştırmanın örneklem grubunu ise; araştırma evreninden basit tesadüfî örnekleme yöntemiyle seçilen 452 çocuk oluşturmaktadır.

Araştırmaya katılan çocukların 236's1 kız, 216's1 ise erkektir. Çocukların 236'sı devam etmekte oldukları anasınıfı veya bağımsız anaokulundan önceki yıllarda da okul öncesi eğitimi almış oup; geriye kalan 216 çocuk ise, önceki yllarda okul öncesi eğitimi almamıştır (Tablo 1).

Tablo 1. Arastrtrmaya Katulan Cocuklarn Betimsel Istatistikleri

\begin{tabular}{llccc}
\hline & & $\begin{array}{c}\text { Daha önceki yıllarda okul } \\
\text { öncesi eğitim almış }\end{array}$ & $\begin{array}{c}\text { Daha önceki yıllarda okul öncesi } \\
\text { eğitim almamiş }\end{array}$ & Toplam \\
\hline Cinsiyet & Kiz & 138 & 98 & 236 \\
& Erkek & 127 & 89 & 216 \\
Toplam & & 265 & 187 & 452 \\
\hline
\end{tabular}

Veri Toplama Araçları

Kişisel Bilgi Formu. Araştırmacılar tarafından hazırlanan Kişisel Bilgi Formu’nda çocuğun cinsiyeti ve okul öncesi eğitim alıp almama durumları hakkında bilgiler yer almaktadır.

Cocuklar İçin Cevresel Tutum Ölçeği (Children's Environmental Attitudes Scale). Çocuklar İçin Çevresel Tutum Ölçeği 2007 yllında Newyork'ta Evans, Brauchle, Haq, Stecker, Wong ve Shapiro tarafindan geliştirilmiştir (s. 636-659). Türkçe uyarlama çalışması ise Cevher-Kalburan (2009, s. 90) tarafindan yapılmıştır. Ölçeğin güvenirlik analizi sonucunda iç tutarlılık katsayısı, Cronbach Alpha $(\alpha)$ değeri .78 olarak bulunmuştur.

TIMI Teele Coklu Zekâ Envanteri (Teele Inventory for Multiple Intelligences). TIMI Teele Çoklu Zekâ Envanteri 1992'de Amerika Birleşik Devletleri'nde Sue Teele tarafindan geliştirilmiştir. TIMI farklı zekâ alanlarına sahip okul öncesi dönem, ilköğretim, lise ve üniversite öğrencilerinin baskın zekâ alanlarını belirlemek için geliştirilmiştir (Teele, 1997, s. 24). Teele'e (2000, s. 2) göre doğacı zekâ kavramının mantıksal-matematiksel zekâ, görsel-uzamsal zekâ, bedensel-kinestetik zekâ, içsel zekâ ve müzikal-ritmik zekâ alanlarının özellikleriyle örtüşmektedir ve doğacı zekâ alanı diğer zekâ alanları üzerine inşa edilmektedir. Bu nedenle ölçeğinde doğa zekâsına yer vermemiştir.

Teele, 1992-1993 yılları arasında TIMI’nın geçerlik ve güvenirlik çalışmasını tamamlamıştır. Geçerlik çalışması, envanterde kullanılan her bir resmin tanımlanan zekâ alanını temsil edip etmediği incelenerek 
yapılmıştır. Güvenirlik çalışması için ise test-tekrar-test yapılmıştır. Güvenirlik çalışması sonucunda, envanterdeki tüm zekâ alanlarının .01 düzeyinde anlamlı olduğu tespit edilmiştir. Bu sonuçlara göre TIMI'nın geçerli ve güvenilir olduğu sonucuna ulaşılmıştır (Teele, 1997, s. 24-38).

Teele Çoklu Zekâ Envanteri'nin Özdemir (2006, s. 96-102) ve Öztürk (2012, s. 42-43) tarafindan Türkçe'ye uyarlama çalışmaları yapılmıştır. Özdemir (2006, s. 96-102) tarafından yapılan çalışmada envanter 15 uzman görüşüne sunularak, kapsam geçerliliğine bakılmıştır ve envanterin Türk çocukları için geçerli olduğu sonucuna ulaşmıştır.

TIMI'nın güvenirlik çalı̧̧ması ise; Özdemir (2006, s. 96-102) ve Öztürk (2012, s. 42-43) tarafından ayrı ayrı gerçekleştirilmiştir. Özdemir (2006, s. 96-102) tarafından yapılan çalışmada, TIMI'nın test-tekrartest güvenirlik katsayılarının sözel-dil zekâ alanında 0.98, mantıksal-matematiksel zekâ alanında 0.93, görsel-uzamsal zekâ alanında 0.94 , müzikal-ritmik zekâ alanında 0.95 , bedensel-kinestetik zekâ alanında 0.95 , içsel zekâ alanında 0.96 ve sosyal zekâ alanında 0.94 olduğu tespit edilmiştir. Test tekrar test sonucunda elde edilen puanlar arasındaki ilişski 0.01 düzeyinde anlamlıdır. Öztürk (2012, s. 42-43) tarafindan yapılan çalışmada ise, envanterin test-tekrar-test güvenirlik katsayılarının sözel-dil zekâ alanında 0.64, mantıksal-matematiksel zekâ alanında 0.53 , görsel-uzamsal zekâ alanında 0.56 , müzikal-ritmik zekâ alanında 0.71 , bedensel-kinestetik zekâ alanında 0.68 , içsel zekâ alanında 0.56 ve sosyal zekâ alanında 0.62 olduğu tespit edilmiştir. Elde edilen sonuçlar zekâ alanlarında pozitif yönlü ve orta düzeyde anlamlı bir ilişki 0.01 olduğunu göstermektedir. Her iki çalışmada elde edilen sonuçlar, TIMI'nın güvenilir bir ölçme aracı olduğunu göstermektedir.

\section{Verilerin Toplanması}

Araştırmada verilerin toplanmasında, "Çocuklar için Çevresel Tutum Ölçeği" ve " Teele Çoklu Zekâ Envanteri” nin, 2014-2015 eğitim-öğretim yllında, Milli Eğitim Bakanlığ1 Konya İl Milli Eğitim Müdürlüğüne bağlı merkez ilçelerinde yer alan ilkokula bağlı anasınıflarına ve bağımsız anaokullarına devam eden 6 yaş çocuklarına uygulanabilmesi için gerekli izinler alınmış ve uygulanacak okullar belirlenmiştir. Örnekleme alınan ilkokulların ve okul öncesi eğitim kurumlarının idarecileri ve öğretmenleriyle görüşülerek araştırma hakkında bilgi verilmiş ve belirtilen ölçekler araştırmacı tarafindan çocuklara uygulanmaya başlanmıştır.

Çocuklara araştırma kapsamında yapılacaklar açılanmış olup çocukların araştırmaya katılımında gönüllülük esası dikkate alınmıştır. Araştırmacı çocuklara ölçekleri bireysel olarak uygulamıştır. Gönüllü olarak araştırmaya katılmak isteyen çocuk okul içerisinde daha önceden hazırlanan, ölçek materyallerinin ve çocukların boyuna uygun masa ve sandalyenin olduğu sessiz bir odaya alınmıştır. Çocuklara etkinlikleri yapmak istemediği zaman bırakabileceği hatırlatılarak ölçekler uygulanmaya başlanmıştır. Etkinliği yarıda bırakmak isteyen çocuklar örnekleme dahil edilmemiştir. Ayrıca ölçek ve envanter, en fazla 20 dakika olmak üzere, ara verilerek çocuklara uygulanmıştır.

"Kişisel Bilgi Formu” doldurulduktan sonra "Çocuklar İçin Çevresel Tutum Ölçeği” uygulanmıştır. Ölçekte 3 oyun yer almaktadır. Birinci ve ikinci oyunda 3 soru; üçüncü oyunda ise 5 soru bulunmaktadır. Birinci oyunda, araştırmacı ile çocuk oyun tahtası üzerindeki yolu ilk tamamlayan olmak için yarışmaktadırlar. Tahtanın üzerinde grafiksel olarak tanımlanan seçenekler (örneğin; içeride televizyon seyretme ya da dişarıda oyun oynama) çocuğa yüksek sesle okunur. Çevreyle ilgili iki alternatif senaryodan oluşan ikinci tutum değerlendirme oyunu keçe tahtası ile oynanmaktadır. Çocuk iki ayrı keçe tahtasındaki iki seçenekli (örneğin; su kirliliğinin çevreye az zarar vermesi veya çok fazla zarar vermesi) durumlar hakkında nasıl hissettiği ile ile ilgili sorulara cevap verir. Üçüncü oyunda ise "endişe etmiyor, biraz endişeli ve çok endişeli” seçeneklerinin olduğu üç farklı yüz ifadelerini gösteren bir endişe termometresi kullanılmıştır (Cevher-Kalburan, 2009, s. 53-54).

Teele Çoklu Zekâ Envanteri'nde sözel-dil, mantıksal-matematiksel, görsel-uzamsal, bedenselkinestetik, müzikal-ritmik, içsel ve sosyal zekâ alanlarından her birine ait sekiz resim olmak üzere farklı etkinlikler yapmakta olan 56 panda resmi yer almaktadır. Bu resimler 28 çift olarak düzenlenmiştir. Çocuklardan bu iki seçenekten kendilerine en çok benzeyeni seçmeleri istenir. Her bir zekâ alanı resmi diğer alanlarla eşleştirilmiştir ve öğrenciler herhangi bir alanı sekiz defa seçebilir. TIMI Teele Çoklu Zekâ Envanterinin uygulanması ve baskın zekâ alanlarını belirlemek oldukça kolaydır. Baskın zeka alanı belirlenirken; her zekâ alanı için belirlenmiş olan rakamlardan oluşan işaretler toplanarak bireylerin her bir zekâ alanlarını temsil eden puanlar hesaplanır. En yüksek puana denk gelen zekâ alanı baskın zekâ alanıdır (Teele, 1997, s. 24-38). 


\section{Verilerin Analizi}

Araştırma verilerinin analizlerinde SPSS paket programı kullanılmış olup betimsel istatistikler, t-Testi, Korelasyon, Regresyon ve iki faktörlü Anova analizlerinden yararlanılmıştır. Çocuklardan elde edilen veriler arasında, Çocukların cinsiyetleri ve okul öncesi eğitim alma ve almama durumları arasında farklılık olup olmadığını belirlemek için t-Testi, çocukların zekâ alanlarıyla çevreye karşı tutumları arasında ilişki olup olmadığını belirlemek için korelasyon analizi ve çocukların çoklu zekâ alanlarının çevreye karşı tutumlarını yordayıp yordamadığını tespit etmek amacıyla çoklu doğrusal regresyon analizi yapılmıştır. Ayrıca okul öncesi dönem çocuklarının çevresel tutum puan ortalamasında cinsiyet ve çoklu zekâ alanlarının puan ortalamalarına göre ve çocukların çevre tutum puan ortalamasında okul öncesi eğitimi alıp almama durumu ve çoklu zekâ alanlarının puan ortalamalarına göre anlamlı düzeyde bir farklılaşma olup olmadığını tespit etmek amacıyla İki Faktörlü Anova analizi yapılmıştır.

\section{Bulgular}

$\mathrm{Bu}$ bölümde, araştırma soruları doğrultusunda bulgulara yer verilmiştir.

1. Okul öncesi dönem çocukların çevreye karşı tutum puan ortalamaları cinsiyete göre anlamlı bir farkl11lk göstermekte midir?

Çocukların çevresel tutum puan ortalamalarında cinsiyete göre anlamlı bir farklılaşma olup olmadığı ttesti ile incelenmiştir. Cinsiyet değişkeni bağımsız değişken, çocukların çevre tutum puanları ise bağımlı değişken olarak alınmıştır, analiz sonuçları Tablo 2'de verilmiştir.

Tablo 2. Cocuklarn Cinsiyet Değiş̧kenine Göre Cevreye Karşı Tutum Puan Ortalamalarna İlişkin t-testi Sonuçlar

\begin{tabular}{|c|c|c|c|c|c|c|}
\hline Grup & $\mathrm{n}$ & $\bar{X}$ & ss & sd & $t$ & $\mathrm{p}$ \\
\hline $\bar{K} 1 z$ & 236 & 21.90 & 2.68 & 450 & -.68 & .49 \\
\hline Erkek & 216 & 22.07 & 2.62 & & & \\
\hline
\end{tabular}

Tablo 2'de yer alan analiz sonuçlarına göre, çocuklarının çevresel tutum puan ortalamaları arasında cinsiyet değiş̧kenine göre anlamlı bir fark görülmemektedir $\left(\mathrm{t}_{(450)}=-.68 ; \mathrm{p}>.05\right)$. Bu bulgu çocukların kız ya da erkek olma durumuna göre benzer çevre tutumuna sahip oldukları şeklinde yorumlanabilir.

2. Okul öncesi dönem çocukların çevreye karşı tutum puan ortalamaları daha önceki yıllarda okul öncesi eğitimi alma veya almama durumlarına (devam etmekte oldukları anasınıfi veya bağımsız anaokulundan önceki anaokulu deneyimleri) göre anlamlı bir farklllık göstermekte midir?

Çocukların çevresel tutum puan ortalamaları devam etmekte oldukları anasınıfı veya bağımsız anaokulundan önceki yıllarda okul öncesi eğitimi alıp almama durumlarına göre anlamlı bir farklılaşma olup olmadığı t-Testi ile incelenmiştir. Çocukların daha önceki yıllarda okul öncesi eğitimi alıp almama durumları bağımsız değişken, çocukların çevresel tutum puan ortalamaları ise bağımlı değişken olarak alınmıştır. Analiz sonuçları Tablo 3'te verilmiştir.

Tablo 3. Cocuklarn Okul Öncesi Ë̆gitim Alp Almama Durumuna Göre Cevreye Karşı Tutum Puan Ortalamalarna Iliskin t-testi Sonuclar

\begin{tabular}{lcccccc}
\hline \multicolumn{1}{c}{ Grup } & $\boldsymbol{n}$ & $\overline{\boldsymbol{X}}$ & $\boldsymbol{s s}$ & $\boldsymbol{S d}$ & $\boldsymbol{t}$ \\
\hline Okul Öncesi Eğitim Almış & 265 & 22.54 & 2.34 & 35 & .33 \\
Okul Öncesi Eğitim Almamış & 87 & 21.19 & 2.86 & & .00 \\
\hline
\end{tabular}

Tablo 3 'te yer alan analiz sonuçlarına göre, çocukların çevreye karşı tutum puan ortalamaları arasında daha önceki ylllarda okul öncesi eğitim alıp almama durumu değişkenine göre okul öncesi eğitimi almış çocuklar lehine anlamlı bir fark bulunmuştur $\left(\mathrm{t}_{(349)}=.33 ; \mathrm{p}<.05\right)$. Okul öncesi eğitimi alan çocukların çevreye karşı tutum puan ortalaması $(\bar{X})=22.54$ iken, okul öncesi eğitimi almamış çocukların çevreye karşı tutum puan ortalaması $(\bar{X})=21.19$ olarak saptanmıştır. Bu bulgu çocukların okul öncesi eğitimi alma ve almama durumlarına göre çevresel tutumlarının okul öncesi eğitimi almış çocuklar lehine bir fark olduğu şeklinde yorumlanabilir. 
3. Okul öncesi dönem çocukların çoklu zekâ puanları ile çevreye karşı tutum puanları arasında ilişki var midir?

Çocukların çoklu zekâ kuramındaki zekâ alan puanları ile çevreye karşı tutum puanları arasında ilişki olup olmadığını incelemek amacıyla pearson korelasyon analizi yapılmıştır (Tablo 4).

Tablo 4. Cocuklarm Çoklu Zekâ Kuramındaki Zekâ Alan Puanlan İle Cevreye Karşı Tutum Puanı Arasındaki Korelasyon Sonuçar

\begin{tabular}{lcc}
\hline \multicolumn{1}{c}{ Zekâ Alanları } & $\boldsymbol{t}$ & $\boldsymbol{p}$ \\
\hline Sözel-Dil Zekâ & -.03 & .51 \\
Mantıksal-Matematiksel Zekâ & -.02 & .68 \\
Görsel-Uzamsal Zekâ & -.02 & .66 \\
Müzikal-Ritmik Zekâ & -.04 & .37 \\
Bedensel-Kinestetik Zekâ & .03 & .55 \\
Sosyal Zekâ & .11 & $.02 *$ \\
İçsel Zekâ & -.02 & .67 \\
\hline
\end{tabular}

Tablo 4 incelendiğinde yapılan korelasyon analiz sonuçlarına göre okul öncesi dönem çocukların sözel-dil zeka ( $\mathrm{r}=-.03, \mathrm{p}>.05)$, mantıksal-matematiksel zeka $(\mathrm{r}=.-02, \mathrm{p}>.05)$, görsel-uzamsal zeka $(\mathrm{r}=.-02$, $\mathrm{p}>.05)$, müzikal-ritmik zeka ( $\mathrm{r}=-.04, \mathrm{p}>.05)$, bedensel-kinestetik zeka $(\mathrm{r}=.03, \mathrm{p}>.05)$ ve içsel zeka $(\mathrm{r}=.02$, $\mathrm{p}>.05)$ alan puanları ile çevreye karşı tutum puanı arasında anlamlı bir ilişki bulunmamıştır.

Çocukların sosyal zekâ puanları ile çevreye karşı tutum puanları arasında düşük düzeyde, pozitif ve anlamlı bir ilişki vardır ( $\mathrm{r}=-.11, \mathrm{p}<.05)$. Buna göre, çocukların sosyal zekâ puanları arttıkça çevresel tutumlarının arttığı söylenebilir. Determinasyon katsayısı $\left(r^{2}=0,12\right)$ dikkate alındığında çocukların çevresel tutumlarının \%12'sinin sosyal zekâ puanından kaynaklandığı söylenebilir.

4. Okul öncesi dönem çocuklarının zekâ alanları, çevresel tutumlarını anlamlı bir şekilde yordamakta midir?

Çocukların sahip oldukları zekâ alanları, çevre tutumlarını anlamlı bir şekilde yordayıp yordamadığı belirlemek için yapılan çoklu regresyon sonuçları Tablo 5'te verilmiştir.

Tablo 5. Cocuklarm Cevreye Karşı Tutumlarmmn Yordanmasına İlişkin Cokelu Doğrusal Regresyon Analizi Sonucları

\begin{tabular}{|c|c|c|c|c|c|c|c|}
\hline Değişken & $\mathbf{B}$ & Sh & Beta & $\mathbf{T}$ & $\mathrm{p}$ & İkili $\mathbf{r}$ & Kısmi r \\
\hline (Sabit) & 1.24 & 21,81 & & .06 & .95 & & \\
\hline Sözel-Dil & .75 & .80 & .45 & .93 & .35 & -.02 & .04 \\
\hline Mantıksal-Matematiksel & .70 & .77 & .42 & .91 & .36 & -.02 & .04 \\
\hline Görsel-Uzamsal & .68 & .77 & .38 & .88 & .37 & -.02 & .04 \\
\hline Müzikal-Ritmiksel & .67 & .78 & .45 & .89 & .37 & -.04 & .04 \\
\hline Bedensel-Kinestetik & .73 & .78 & .41 & .94 & .34 & .03 & .04 \\
\hline İçsel & .69 & .78 & .35 & .88 & .37 & -.02 & .04 \\
\hline Sosyal & .90 & .78 & .52 & 1.15 & .25 & .11 & .05 \\
\hline $\mathrm{R}=.12$ & $R^{2}=.02$ & $\mathrm{n}=452$ & & & & & \\
\hline$F_{(7-444)}=.94$ & $\mathrm{p}=.475$ & & & & & & \\
\hline \multicolumn{8}{|c|}{ Bağımsız değişken: Zekâ Alanları } \\
\hline
\end{tabular}

Tablo 5’te görüldüğü üzere çocukların zekâ alanlarının çevreye karşı tutumlarını anlamlı bir şekilde yordamadığı saptanmıştır $\left(\mathrm{R}=, 12 ; R^{2}=, 02 ; \mathrm{F}_{(7-444)}=, 475 ; \mathrm{p}>.05\right)$. Enter metodu kullanılarak yapılan çoklu doğrusal regresyon analizinin katsayılarına bakıldı̆̆ında çocukların sahip oldukları zekâ türleri, çevresel tutumlarının \% 2'sini açıkladığı, ancak bu yordama değerinin anlamlı olmadığ1 tespit edilmiştir. Bu bulgu çocukların çevreye karşı tutumları üzerinde, sahip oldukları zekâ türlerinin etkisinin olmadığı şeklinde yorumlanabilir.

5. Okul öncesi dönem çocuklarının çevreye karşı tutum puan ortalaması okul öncesi eğitimi alıp almama durumları ve çoklu zekâ puanlarının ortalamalarına göre anlamlı düzeyde farklılaşmakta mıdır?

Çocukların çoklu zekâ alanları ve okul öncesi eğitimi alıp almama durumlarına göre çevreye karşı tutum puan ortalamalarına ilişkin betimsel istatistikler Tablo 6'da verilmiştir. 
Tablo 6. Çoklu Zekâ Puanlar ve Okul Öncesi Eğitimi Alph Almama Durumlarnna Göre Cevreye Karşı Tutum Puanlarnnn Betimsel Istatistikleri

\begin{tabular}{lllll}
\hline & OÖE alma/almama durumu & $\bar{X}$ & ss & $n$ \\
\hline Çoklu Zekâ & OÖE almış & 22.54 & 2.34 & 236 \\
Alanları & OÖE almamiş & 21.19 & 2.86 & 216 \\
& Toplam & 21.98 & 2.65 & 452 \\
\hline
\end{tabular}

Tablo 6'te yer alan betimsel istatistik sonuçlarına göre okul öncesi eğitim almış çocukların çevreye karşı tutum ortalama puanı $(\bar{X})=22.54$ ve okul öncesi eğitim almamış çocukların çevreye karşı tutum puan ortalamasi ise $(\bar{X})=21.19^{\prime}$ dur.

Çocuklarının çevreye karşı tutum puan ortalamaları okul öncesi eğitimi alıp almama durumu ve çoklu zekâ alanlarının puan ortalamalarına göre anlamlı bir farklılaşma olup olmadığı iki faktörlü ANOVA analizi sonuçları Tablo 7'de verilmiştir.

Tablo 7. Okul Öncesi Eğitimi Alph Almama Durumu Ve Çoklu Zekâ Alanlarna Göre Çevresel Tutum Puan Ortalamalarmin İki Faktörlï ANOV A Sonuclar

\begin{tabular}{|c|c|c|c|c|c|c|}
\hline Varyansın Kaynağı & $\begin{array}{c}\text { Kareler } \\
\text { Toplam1 }\end{array}$ & $S d$ & $\begin{array}{c}\text { Kareler } \\
\text { Ortalamasi }\end{array}$ & $F$ & $(p)$ & $\eta^{2}$ \\
\hline Okul Öncesi Eğitim & 154.54 & 1 & 154.54 & 23.48 & $.00^{*}$ & .05 \\
\hline Sözel-Dil Zekâ & 52.30 & 7 & 7.47 & 1.13 & .34 & .01 \\
\hline O.Ö.E.*S.D.Z. & 50.63 & 7 & 7.23 & 1.09 & .36 & .01 \\
\hline Hata & 2869.73 & 436 & 6.58 & & & \\
\hline Okul Öncesi Eğitim & 82.55 & 1 & 82.55 & 12.69 & $.00^{*}$ & .02 \\
\hline Mantıksal-Matematiksel Zekâ & 57.15 & 8 & 7.14 & 1.09 & .36 & .02 \\
\hline O.Ö.E.*M.M.Z & 80.77 & 7 & 11.54 & 1.77 & .09 & .02 \\
\hline Hata & 2829.79 & 435 & 6.50 & & & \\
\hline Okul Öncesi Eğitim & 41.72 & 1 & 41.72 & 6.44 & $.01^{*}$ & .01 \\
\hline Görsel-Uzamsal Zekâ & 110.89 & 8 & 13.86 & 2.14 & $.03^{*}$ & .03 \\
\hline O.Ö.E.*G.U.Z. & 44.36 & 6 & 7.39 & 1.14 & .33 & .01 \\
\hline Hata & 2821,25 & 436 & 6.47 & & & \\
\hline Okul Öncesi Eğitim & 49.64 & 1 & 49.64 & 7.52 & $.00^{*}$ & .01 \\
\hline Müzikal-Ritmik Zekâ & 50.99 & 8 & 6.37 & .96 & .46 & .01 \\
\hline O.Ö.E.*M.R.Z. & 56.94 & 8 & 7.11 & 1.07 & .37 & .02 \\
\hline Hata & 2862.37 & 434 & 6.59 & & & \\
\hline Okul Öncesi Eğitim & 159.38 & 1 & 159.13 & 25.09 & $.00^{*}$ & .05 \\
\hline Bedensel-Kinestetik Zekâ & 87.24 & 8 & 10.90 & 1.71 & .09 & .03 \\
\hline O.Ö.E.*B.K.Z. & 133.62 & 7 & 19.09 & 3.01 & $.00^{*}$ & .04 \\
\hline Hata & 2759.23 & 435 & 6.34 & & & \\
\hline Okul Öncesi Eğitim & 96.42 & 1 & 96.42 & 14.94 & $.00^{*}$ & .03 \\
\hline Sosyal Zekâ & 112.17 & 8 & 14.02 & 2.17 & $.02 *$ & .03 \\
\hline O.Ö.E.*S.Z. & 39.10 & 7 & 5.58 & .86 & .53 & .01 \\
\hline Hata & 2806.92 & 435 & 6.45 & & & \\
\hline Okul Öncesi Eğitim & 61.05 & 1 & 61.05 & 9.16 & $.00^{*}$ & .02 \\
\hline İçsel Zekâ & 39.43 & 7 & 5.63 & .84 & .55 & .01 \\
\hline O.Ö.E.* İ.Z. & 14.65 & 6 & 2.44 & .36 & .90 & .00 \\
\hline Hata & 2911.90 & 437 & 6.66 & & & \\
\hline TOPLAM & 3168.82 & 451 & & & & \\
\hline
\end{tabular}

Yukarıdaki tablo incelendiğinde okul öncesi eğitimi alıp alamama durumunun çevreye karşı tutum puan otalaması üzerindeki ayrı etkisinin anlamlı olduğu bulunmuştur $(\mathrm{p}<.05)$. Buna göre okul öncesi eğitimi alıp almama durumunun, çocukların çevre tutum puanlarını etkileyen bir faktör olduğu şeklinde yorumlanabilir.

Çoklu zekâ alanlarının (yedi farklı zekâ alanının) çevreye karşı tutum puan ortalaması üzerindeki etkisi ayrı olarak ele alındığında ise; çocukların sözel-dil zekâ alanının $\left[\mathrm{F}_{(1,436)}=1.13 ; \mathrm{p}>.05\right]$, mantıksalmatematiksel zekâ alanının $\left[\mathrm{F}_{(1,435)}=1.09 ; \mathrm{p}>.05\right]$, müzikal-ritmik zekâ alanının $\left[\mathrm{F}_{(1,434)}=.96 ; \mathrm{p}>.05\right]$, bedensel-kinestetik zekâ alanının $\left[\mathrm{F}_{(1,435)}=1.71 ; \mathrm{p}>.05\right]$, içsel zekâ alanının $\left[\mathrm{F}_{(1,437)}=.84 ; \mathrm{p}>.05\right]$, çevreye karşı tutum puan ortalaması üzerindeki etkisinin anlamlı olmadığı bulunmuştur. Bu durum çocukların çevre tutum puanları üzerinde sözel-dil zekâ, mantıksal-matematiksel zekâ, müzikal-ritmik zekâ, bedensel- 
kinestetik zekâ ve içsel zekâ alanlarının önemli bir etkisinin olmadığını göstermektedir. Ancak görseluzamsal zekâ $\left[\mathrm{F}_{(1,436)}=2.14 ; \mathrm{p}<.05\right]$ ve sosyal zekâ $\left[\mathrm{F}_{(1,435)}=2.17 ; \mathrm{p}<.05\right]$ alanları puan ortalamalarının çevreye karşı tutum puan ortalaması üzerindeki etkisinin istatistiksel olarak anlamlı olduğu tespit edilmiştir. Buna göre görsel-uzamsal zekâ ve sosyal zekâ alanların çocukların çevre tutum puan ortalamalarını etkileyen bir faktör olduğu bulunmuştur.

Okul öncesi eğitim alma ve almama durumu ve sözel-dil zekâ alanının $\left[\mathrm{F}_{(1,436)}=1.09 ; \mathrm{p}>.05\right]$, mantıksal-matematiksel zekâ alanının $\left[\mathrm{F}_{(1,435)}=1.77 ; \mathrm{p}>.05\right]$, görsel-uzamsal zekâ alanının $\left[\mathrm{F}_{(1,436)}=1.14\right.$; p>.05], müzikal-ritmik zekâ alanının $\left[\mathrm{F}_{(1,434)}=1.07 ; \mathrm{p}>.05\right]$, içsel zekâ alanının $\left[\mathrm{F}_{(1,437)}=.36 ; \mathrm{p}>.05\right]$ ve sosyal zekâ alanının $\left[\mathrm{F}_{(1,435)}=.86 ; \mathrm{p}>.05\right]$, çocukların çevreye karşı tutumları üzerindeki ortak etkisinin anlamlı olmadığı bulunmuştur. Başka bir ifadeyle, daha öncesinde okul öncesi eğitimi alıp almama durumlarına göre ve sözel-dil, mantıksal-matematiksel, görsel-uzamsal, müzikal-ritmik, içsel, sosyal zekâ alanlarına göre çevreye karşı tutum puanlarının farklılık göstermediği anlaşılmaktadır. Ancak okul öncesi eğitimi almış ve almamış olma durumu ve bedensel-kinestetik zekâ alanının, çevreye karşı tutum puanları üzerinde ortak etkisinin anlamlı olduğu bulunmuştur $\left[\mathrm{F}_{(1,435)}=.00 ; \mathrm{p}<.05\right]$. Başka bir ifadeyle, çevreye karşı tutum puanlarının okul öncesi eğitim alma ve almama durumuna ve bedensel-kinestetik zekâ alanına göre farklılık gösterdiği anlaşılmaktadır. Okul öncesi eğitimi alan bedensel-kinestetik zekâ alanına sahip çocukların çevresel tutum ortalama puanı $(\bar{X})=22.54$ ve okul öncesi eğitimi almamış bedensel-kinestetik zekâ alanına sahip çocukların çevresel tutum ortalama puanı $(\bar{X})=21.18$ 'dir.

\section{Tartışma, Sonuç ve Öneriler}

Araştırma sonucu okul öncesi dönem çocuklarının cinsiyetlerine göre çevreye karşı tutum puan ortalamaları arasında anlamlı bir farklılık bulunmadığını göstermektedir. Okul öncesi dönem çocuklarının çevreye karşı tutumlarını cinsiyet faktörüne göre inceleyen çalışmaların sonuçları, bu araştırmanın sonucunda elde edilen bulguları destekler niteliktedir. Musser ve Diamond (1999, s. 27) ve KahrimanÖztürk (2010, s. 112) okul öncesi dönem çocuklarının çevresel tutumlarının cinsiyete göre farklilık göstermediğini tespit etmişlerdir. Ayrıca Çabuk (2001, s. 75) okul öncesi dönem çocuklarının çevre ile ilgili farkındalık düzeylerinde cinsiyetlerine göre istatistiksel olarak anlamlı bir farklılık olmadığını ortaya koymuştur.

Kesicioğlu (2008, s. 68) okul öncesi dönem çocuklarının çevresel tutumlarını cinsiyete göre farklılık gösterip göstermediğini incelemiştir. Yapılan çalışmada çocukların cinsiyeti ile doğa unsurlarına karşı tutumları arasında anlamlı bir farklılık olduğu ve erkek çocukların kız çocuklara göre doğa unsurlarına karşı tutumlarının daha olumlu olduğu sonucuna ulaşılmıştır. Bu bulgu, çocukların cinsiyeti ile doğa unsurlarına karşı tutumları arasında bir ilişki olduğunu göstermektedir.

Araştırma sonucu, çocukların okul öncesi eğitim alıp almama durumu değişkenine göre çevreye karşı tutum puanları arasında okul öncesi eğitimi almış çocuklar lehine anlamlı bir farklılık olduğunu göstermektedir. Araştırma sonucunda elde edilen bu bulgu, okul öncesi eğitimin çocuklarda çevreye karş1 olumlu tutum oluşmasında önemli bir etkendir şeklinde yorumlanabilir. Okul öncesi eğitim, çocuklarda çevreye yönelik olumlu tutum geliştirilmesinde önemli bir yere sahiptir. Ancak bu araştırmada elde edilen sonuçtan farklı olarak, Çabuk (2001, s. 75) tarafından yapılan çalışmada, okul öncesi dönem çocuklarının daha önce başka bir okul öncesi eğitim kurumuna gidip gitmediğinin ve gittiği diğer kuruma devam etme süresinin çevresel farkındalıklarına etkilerinin olmadığı saptanmıştır.

Araştırmada okul öncesi dönem çocuklarının sosyal zekâ puanları ile çevreye karşı tutum puanları arasında pozitif yönde düşük düzeyde anlamlı bir ilişki olduğu saptanmışır. Araştırma sonucunda elde edilen bu bulguya göre, okul öncesi dönem çocuklarının sosyal zekâ alanı geliştikçe çocukların çevreye karşı tutumlarının da arttı̆̆ı söylenebilir. Sosyal zekâ alanının göstergelerinden olan empati ve başkalarını anlama yeteneği, çevre ile ilişkilerde önemli rol oynar. Bu nedenle birey ile çevre arasındaki ilişkilerde, bireyin çevreyi anlama, çevresindeki varlıklarla empati kurma yeteneğinin gelişmesinin, bireyde olumlu çevresel tutum oluşmasında etkili olabileceği şeklinde açıllanabilir.

$\mathrm{Bu}$ araştırma sonucunda çoklu zekâ alanlarının çevre tutumunu düşük düzeyde yordadığı görülmektedir. Bu durum ile, araştırmanın çalışma grubuna alınan çocukların çoklu zekâ alanlarından daha farklı değişkenlerin çevreye karşı tutumlarını açıkladığı düşünülebilir.

Araştırma sonucu çoklu zekâ alanlarının çevreye karşı tutum puan ortalaması üzerindeki etkisi ayrı olarak ele alındığında ise; çocukların sözel-dil zekâ alanının, mantıksal-matematiksel zekâ alanının, müzikalritmik zekâ alanının, bedensel-kinestetik zekâ alanının, içsel zekâ alanının, çevreye karşı tutum puan 
ortalaması üzerindeki etkisinin anlamlı olmadığını göstermektedir. Bunun yanı sıra görsel uzamsal zekâ ve sosyal zekâ alanları ile çevreye karşı tutum puan ortalamalarında anlamlı bir farklılık olduğunu göstermektedir. Görsel uzamsal zekâsı baskın olan çocuklar çevrelerini doğru bir şekilde algıladı̆̆ından (Armstrong, 2009, s. 75) çevreleri hakkında daha çok deneyime ve bilgiye sahip olabilir. Dolayısıyla çocuğun görsel uzamsal zekâsının baskın olmasının, çevreye yönelik olumlu tutum geliştirmesine katkısı olduğu söylenebilir.

Araştırmada çocukların daha önceki yıllarda okul öncesi eğitimi alma durumlarının ve zekâ alanlarının çevreye karşı tutum puanlarına ortak etkisine bakıldığında okul öncesi eğitimi alma durumu ve bedensel kinestetik zekâ alanının ortak etkisinin anlamlı olduğu sonucuna ulaşılmıştır. Bu durum okul öncesi eğitimde çevresel tutum geliştirmeye yönelik yapılan etkinliklerin, çoğunlukla çocukların bedensel kinestetik zekâ alanına yönelik etkinlikler olduğunu düşündürmektedir.

Bedensel-kinestetik zekâ bireyin bedenini kullanarak kendini ifade etme becerisidir. Bu zekâ alanında gelişmiş bireyler; el becerilerini kullanmayı sever, dokunarak ve hareket ederek öğrenir (Kansu, 2012, s. 14). Okul öncesi eğitim kurumlarında verilen çevre eğitimine ilişkin etkinlikler, daha çok çocukların hareket becerilerini geliştirmeye yönelik kazanımları içerebilir. Bu nedenle okul öncesi eğitim alma durumu ve bedensel-kinestetik zekânın çevreye karşı tutumu etkilediği söylenebilir. Ayrıca araştırma sonucu çocukların okul öncesi eğitimi alma durumlarının ve çoklu zekâ alanlarından sözel-dil zekâ, mantıksalmatematiksel zekâ, görsel-uzamsal zekâ, bedensel-kinestetik zekâ, içsel zekâ ve sosyal zekâ alanlarının çevreye karşı tutum puanlarına ortak etkisinin anlamlı olmadığını göstermektedir. Bu araştırma sonucuna yönelik olarak okul öncesi dönem çocuklarına yönelik çalışmalara araştırmacılar tarafindan rastlanılmamış olup farklı eğitim kademelerindeki benzer çalışmalar aşağıda açıklanmıştır.

Arslanyolu (2010, s. 58), ilköğretim öğrencilerinin sözel zekâ alanı hariç; matematiksel-mantıksal zekâ, görsel-uzamsal zekâ, müzikal zekâ, bedensel-kinestetik zekâ, sosyal zekâ, içsel zekâ ve doğaci zekâ alanlarının düzeyinin çevreye yönelik tutum üzerinde olumlu etkisi olduğunu tespit etmiştir. Kahyaoğlu (2013, s. 74-75) yaptı̆̆1 araştırmada ortaöğretim öğrencilerinin sözel-dil ve müzikal zekâ ile çevresel tutumları arasında anlamlı bir farklılık olduğu diğer zekâ alanları ile çevresel tutumları arasında anlamlı bir farklılığın olmadığını bulmuştur. Baş (2010, s. 53-74) çoklu zekâ kuramına dayalı öğretim yönteminin ilköğretim öğrencilerinin çevresel farkındalık, tutum ve bilgi düzeylerine etkisini incelemek amacıyla; 20092010 eğitim öğretim yılında 60 öğrencinin katılımıyla deneysel çalısma yapmışıı. Araştırmada deney grubundaki öğrencilere çoklu zekâ kuramına dayalı öğretim yöntemiyle, kontrol grubundaki öğrencilere ise geleneksel öğretim yöntemleriyle hazırlanan çevre eğitimi programları uygulanmıştır. Araştırma sonucu, çoklu zekâ kuramina dayalı öğretim yönteminin öğrencilerin çevresel farkındalık, tutum ve bilgi düzeylerinde geleneksel yönteme göre daha etkili olduğunu ortaya koymuştur.

Araştırma sonucundan yola çıkılarak şu önerilerde bulunulabilir;

- Araştırmacılar, okul öncesi dönemdeki çocukların çoklu zekâ alanlarının çevresel tutumlarına etkisini inceleyen deneysel desende çalışmalar yapabilir.

- Eğitimciler, okul öncesi dönemdeki çocuklara çevre eğitimi etkinlikleri planlarken ve uygularken; grup, ekip ve işbirlikli çalısmalar, proje çalısmaları ve eşli çalışmalar gibi sosyal becerileri içeren etkinlikler olmasına özen gösterebilir.

\section{Etik Beyan}

“Okul Öncesi Dönem Çocuklarının Çoklu Zekâ Alanları ile Çevreye Karşı Tutumlarının İncelenmesi” başlıklı çalışmanın yazım sürecinde bilimsel, etik ve alıntı kurallarına uyulmuş; toplanan veriler üzerinde herhangi bir tahrifat yapılmamış ve bu çalışma herhangi başka bir akademik yayın ortamına değerlendirme için gönderilmemiştir.

\section{Kaynakça}

Andrejewski, R. (2011). Nature connection, outdoor play and environmental stewardship in residential environmental education (Doctoral Dissertation). The Pennsylvania State University, Pennsylvania.

Armstrong, T. (2009). Multiple intelligences in the classroom. Alexandria: ASCD.

Arslanyolu, K. (2010). Illkögretim ögrencilerinin çevreye karşı tutumlarmın çoklu zekêa kuramına göre incelenmesi (Yayınlanmamış yüksek lisans tezi). Erzincan Üniversitesi Sosyal Bilimler Enstitüsü, Ankara. 
Baş, G. (2010). The effects of multiple intelligences instructional strategy on the environmental awareness knowledge and environmental attitude levels of elementary students in science course. International Electronic Journal of Environmental Education, 1(1), 53-80.

Bogner, F. X. ve Wiseman. M. (2006). Adolescents' attitudes towards nature and environment: quantifying the MEV model. The Environmentalist, 26(4), 247-254.

Bruni, C. M., Chance, R. C. ve Schultz, P. W. (2012). Measuring values-based environmental concerns in children: An environmental motives scale. The Journal of Environmental Education, 43(1), 1-15.

Buhan, B. (2006). Okul öncesinde görev yapan ögretmenlerin çevre bilinci ve bu okullardaki çevre eğitiminin araştırlması (Yüksek Lisans Tezi). Marmara Üniversitesi Eğitim Bilimleri Enstitüsü, İstanbul.

Cevher-Kalburan, F. N. (2009). Cocuklar için çevresel tutum ölçeği" ile "yeni ekolojik paradigma ölçĕginin" geçerlik güvenirlik çalşsmasi ve çevre eğitimi programmnn incelenmesi (Doktora Tezi). Gazi Üniversitesi Eğitim Bilimleri Enstitüsü, Ankara.

Çabuk, B. (2001). Okul öncesi dönem çocklarmın çevre ile ilgili farkendahle düzeyleri (Yüksek Lisans Tezi). Ankara Üniversitesi Fen Bilimleri Enstitüsü, Ankara.

Demirel, Ö., Başbay, A. ve Erdem, E. (2006). Eğitimde çoklu zekâa kuram ve uygulama. Ankara: Pegem Akademi Yayınc1lik.

Erten, S. (2004). Çevre egitimi ve çevre bilinci nedir, çevre egitimi nasıl olmalıdır? Cevre ve İnsan Dergisi, 65/66.

Evans, G. W., Brauchle, G., Haq, A., Stecker, R., Wong, Kve \& Shapiro, E. (2007). Young children's environmental attitudes and behaviors. Environment and Behavior, 39(5), 636-659.

Fleetham, M. (2006). Multiple intelligence in practice, enhacing self esteem and learning in the classroom. Stafford: Network Continuum Education.

Fleetham, M. (2014). Pocket pal: multiple intelligences. London: Bloomsbury.

Gardner, H. (2011). Frames of mind. New York: Basic Books Publishing.

Haktanır, G. (2007). Okul öncesi dönemde çevre eğitimi. İçinde: Cevre eğitimi. Ankara: Türkiye Çevre Vakfı Yayını.

Kahriman-Öztürk, D. (2010). Preschool chıldren's attıtudes towards selected envrronmental issues (Yüksek Lisans Tezi). Orta Doğu Teknik Üniversitesi Sosyal Bilimler Enstitüsü, Ankara.

Kahyaoğlu, M. (2013). Ortaöğretim öğrencilerinin zekâ alanları ile çevreye yönelik tutumları arasındaki ilişkinin değerlendirilmesi. Ankara Üniversitesi Eğitim Bilimleri Fakültesi Dergisi, 46(2), 159-178.

Kansu, N. (2012). Cocuğumla doğadayı: çocuğumun zeka alanlarm gelistiriyorum. Ankara: Elma Yayınevi.

Karasar, N. (2014). Bilimsel araștırma yöntemi. Ankara: Nobel Akademik Yayıncıllı.

Kesicioğlu, O. S. (2008). Ebeveynlerin okul öncesi dönemdeki çocuklarna yaşattıklar doğal çevre deneyimleri ve çocuklarn çevreye karşı tutumlar (Yüksek Lisans Tezi). Gazi Üniversitesi Eğitim Bilimleri Enstitüsü, Ankara.

Liefländer A. K. ve Bogner F. X. (2018) Educational impact on the relationship of environmental knowledge and attitudes. Environmental Education Research, 24(4), 611-624.

Mert, M. (2006). Lise ögrencilerinin çevre eğitimi ve katı atıklar konusundaki bilinc düzeyinin saptanması (Yüksek Lisans Tezi). Hacettepe Üniversitesi Eğitim Bilimleri Enstitüsü, Ankara.

Miller, D. L. (2007). The seeds of learning: young children develop important skills through their gardening activities at a midwestern early education program. Applied Environmental Education \& Communication, 6(1), 49-66.

Monroe, M. C., Andrews, E. ve Biedenweg, K. (2007). A framework for environmental education strategies. Applied Environmental Education and Communication, 6, 205-216.

Musser, L. M. ve Diamond, K. E. (1999). The children's attitudes toward the environment scale for preschool children. The Journal of Environmental Education, 30(2), 23-30.

Özdemir, B. (2006). 4-6 yas grubu ögrencilerinin ögrenme sürecinde çoklu zekâ teorisinin yeri (Yüksek Lisans Tezi). Çanakkale On Sekiz Mart Üniversitesi Sosyal Bilimler Enstitüsü, Çanakkale.

Özdemir, O. (2007). Yeni bir çevre eğitimi perspektifi: “sürdürülebilir gelişme amaçlı eğitim”. Eğitim ve Bilim, 32(145), 23-39.

Öztürk, M. B. (2012). Anasınfina devam eden farkl sosyoekonomik düreydeki çocuklarn çoklu zekâa alanlarmm incelenmesi (Yüksek Lisans Tezi). Hacettepe Üniversitesi Sosyal Bilimler Enstitüsü, Ankara.

Saban, A. (2010). Coklu zekâ kuramı ve Türk eğitim sistemine yansıması. Ankara: Nobel Yayınevi.

Schultz, P., Shriver, C., Tabanico, J. ve Khazian, A. (2004). Implicit connections with nature. Journal of Environmental Psychology, 24(1), 31-42.

Şahin, N. F., Cerrah, L., Saka, A. ve Şahin, B. (2004). Yüksek öğretimde öğrenci merkezli çevre eğitimi dersine yönelik bir uygulama. Gaz̧i Eğitim Fakültesi Dergisi, 24(3), 113-128.

Tanrıverdi, Ö. (2012). Yaratıcı drama yöntemi ile verilen eğitimin okul öncesi ögrencilerinin çevre farkındalı̆ğna etkisi (Yüksek Lisans Tezi). Muğla Sitkı Koçman Üniversitesi Eğitim Bilimleri Enstiütüsü, Muğla.

Teele, S. (1997). Teele inventory of multiple intelligences. Redlands California: Teele ve Associtates.

Teele, S. (2000). Rainbows of intelligence: Exploring how students learn. California: Corwin Press.

Tuğrul, B. ve Duran, E. (2003). Her çocuk başarılı olmak için bir şansa sahiptir: zekânın çok boyutluluğu çoklu zekâ kuramı. Hacettepe Üniversitesi Ë̆itim Fakültesi Dergisi, 24, 224-233.

UNESCO/UNEP. (1977). Intergovermental conference on environmental education. http://unesdoc.unesco.org/images/0003/000327/032763eo.pdf adresinden 02/08/2018 tarihinde erişilmiştir. $3(1), 1-8$. 


\section{EXTENDED ABSTRACT}

Increasing environmental problems threaten not only human beings but also other creatures (Bruni, Chance, \& Schultz, 2012, p. 1). To live in a healthy and clean world, it is necessary to educate individuals who are conscious about the environment and who are environmentally sensitive (Mert, 2006, p. 66; Şahin, Cerrah, Saka, \& Şahin, 2004, p. 114; Özdemir, 2007, p. 25).

Environmental attitude refers to the emotions, beliefs and behaviors that the individual has towards environmental issues as well as using and protecting environment (Bogner, \& Wiseman, 2006, p. 247-254; Schultz, Shriver, Tabanico, \& Khazian, 2004, p. 31). It is possible to ensure that children gain positive attitudes towards environment, that they empathize with environment, and that they love nature by proving environmental education in educational environments, starting from the pre-school period (Andrejewski, 2011, p. 150; Erten, 2004, p. 3-4; Kesicioğlu, 2008, p. 67-71; Özdemir, 2007, p. 38).

Children's interest and sense of wonder should be taken into account while doing practices related to environmental education as young kids are very curious about and interested in the world (Buhan, 2006, p. 37). Children's development in different intelligence areas can be supported through the theory of multi intelligence, by identifying their intelligence areas, by applying curriculum in line with their interests and abilities, and by giving equal attention to all intelligence areas (Saban, 2010, p. 2).

Gardner argues that the ability to solve a problem or to produce a product in a different way should be called intelligence. According to these characteristics, he has defined eight different intelligence areas (Gardner, 2011, p. 63-74).

Examining the attitudes of children (according to different intelligence areas they have) towards the environment during the pre-school period where the environmental education is laid is important as it reveals the differences between children's interests and abilities in environmental education and considers individual differences while preparing the curriculum.

When the literature was examined, it was found that there were few studies examining the relationship between children's environmental attitude and multiple intelligence areas. However, these studies did not include pre-school children and they were about other education levels (Arslanyolu, 2010, p. 2; Baş, 2010, p. 59-60; Kahyaoğlu, 2013, p. 163). Therefore, this study aimed to examine the attitudes of pre-school children towards environment and multiple intelligence areas in the environmental education, taking into account their individual differences, interests, and abilities.

The general survey method was used in this research. The sample consisted of 452 pre-school children who were living in Meram, Konya and chosen randomly. Personal Information Form, TIMI (Teele Inventory for Multiple Intelligences) and Children's Environmental Attitude Scale were used as data collection tools. Data were analyzed via SSPS 17.00. Descriptive statistics, correlation, t-test, regression, two-factor ANOVA, was used for data analysis.

According to results, considering whether children received pre-school education or not variable, it was found that there was a significant difference between the attitude scores of children towards the environment in favor of children who had received pre-school education. Thus, it can be concluded that the outcomes in pre-school curriculum are an important factor in developing positive attitude towards environment in children. In a study by Çabuk $(2001$, p. 75$)$, it was determined that the duration of preschool education did not have any effect on environmental awareness

In the study, it was found that there was a positively low correlation between the interpersonal-social intelligence scores of the children and their attitude towards the environment. Empathy and the ability to understand others, which are indicators of interpersonal-social intelligence, play an important role in relations with the environment. Therefore, it can be explained that the relationship between the individual and the environment can be effective in the development of positive environmental attitudes as a result of the development of the ability of the individual to understand the environment, the empathy with the environment and the beings around it.

It can be said that individual's ability to understand the environment and to empathize with creatures around him or her can be improved by developing the interpersonal-social intelligence areas, and that it can be effective in the forming positive environmental attitudes. 
In the study, a significant difference was found when the common effect of children's pre-school education in previous years and their physical-kinesthetic intelligence area on scores of children's attitude towards environment was examined. Physical-kinesthetic intelligence is a type of intelligence associated with the whole body and hands. It is individual's ability to use his body to express himself. Individuals who are advanced in this area cannot sit still for a long time; they like to use manual skills and they learn by touching and moving (Kansu, 2012, p. 14). It can be said that the effect of pre-school education and physical kinesthetic intelligence has an effect on the environment since environmental activities in institutions require children to use their movement skills and bodies.

According to the study results, it is recommended that educators should support pre-school children in developing their attitudes towards the environment by applying environmental education programs to them. While implementing environmental education programs, activities such as group, team and cooperative works, project studies and co-operative activities can be organized. 